\title{
WOMEN EMPOWERMENT IN A RURAL MATRILINEAL SOCIETY OF MEGHALAYA, INDIA
}

\author{
Minakshi Keeni*, Nina Takashino, A.K. Nongkynrih and Katsuhito Fuyuki \\ Department of Resource and Environment Economics, Faculty of Agricultural Science, Tohoku \\ University, Sendai, Japan. \\ ${ }^{*}$ Corresponding author e-mail: minakshikeeni@gmail.com
}

Citation: Keeni, M., Takashino, N., Nongkynrih, A.K., and Fuyuki, K., 2018. Women Empowerment in a Rural Matrilineal Society of Meghalaya, India. J. Asian Rur. Stud. 2(2): 144-152

\begin{abstract}
The present study was undertaken to ascertain whether rural women are empowered in a matrilineal society in India. In a state where traditional institutions function on the basis of local customs and conventions that are not codified and yet religiously followed, it is questionable to whether the women are essentially empowered. In such a scenario, one wonders if owning land is enough to empower a woman. The objective of this study is to check if whether land ownership empowers a woman and if it gives her decision-making power in the household. The study was conducted at one village from each of the two districts in Meghalaya- the East Khasi Hills and the West Khasi Hills. Fifty female respondents from each district were made to answer a structured questionnaire, after which four respondents had to be eliminated, as they were unmarried and eighteen respondents had to be dropped as they were either a widow or separated. Probit regression was then used to analyze the data. The results stated that women who inherited land were more likely to have a savings account and be a part of a socio-economic group. From this it can be concluded, that women who owned land through lineage were empowered, however the fact that they still consider their husbands to be the head of the family, makes us consider that there may be a psychological component to it.
\end{abstract}

Keywords: Meghalaya; Matrilineal Society; Women Empowerment

\section{Introduction}

In a fast-developing nation like India, the empowerment of women and the reduction of gender inequalities comprise a major part of the development policy. Gender equality is one of the 17 Global Goals of the 2030 Agenda for Sustainable Development of India (UNDP, 2015).

Land is a major indicator of an individual's social status (Ghosh and Chowdhury, 2009). Like a landlord or a capitalist, the patriarch typically owned and controlled the means of production, and could impose economic sanctions on his agents, or workers. He had a legal claim on the labor and income of his wife and children and was required by law to provide them, in return, with a subsistence income (Braunstein and Folbre, 2001). Consequently, women tend to become economically dependent on their male counterparts, leading to a reduction in the empowerment quotient (Giovarelli and Wamalwa, 2011). Entitling women with land could on the one hand empower them economically, and on the other hand strengthen their ability to challenge social and political gender inequalities, both within and outside the home (Agarwal, 2000). Empowerment is a process, that expands women's agency 
or, more simply put, it is an increase in women's ability to make choices about their lives and environment (Malhotra \& Schuler, 2005). Based on this understanding of empowerment, land ownership should act as a source of empowerment by increasing women's security and influence and increasing their control over household decisions (Agarwal, 1997; Haddad, Hoddinott \& Alderman, 1997).

Twenty-one of the 63 countries studied by Htun and Weldon (2011) have unequal inheritance rights for men and women. There is a bidirectional relationship between economic development and women's empowerment defined as improving the ability of women to access the constituents of development-in particular health, education, earning opportunities, rights, and political participation (Duflo, 2012). Women in Gujarat who participated in a loan program which insisted on joint legal titles for the husband and wife on land said that they gained security from the joint title, in that the family would not expel them from the household, nor sell the land without their permission (Unni,1999). Similarly, in Rajasthan, it was found that widows who owned land were given greater respect and consideration than widows who did not (Agarwal, 1994).

Matriliny is an uncommon but a recurrent type of social organization found in the world. In the Standard Cross-Cultural Sample, 31 of 186 societies (17\%) are matrilineal (Murdock $\&$ White, 1969). In India, the basic units of society are patrilineal in nature, with very few exceptions. Meghalaya and Kerala are two states in India where matriliny is known to be practised. While various studies concerning women's issues in patrilineal societies can be found (Kurian, 2004; Kulwiki, 2002) or Kerala (Mitra and Singh, 2007; Chacko, 2003; Jeffrey, 2005) with very little research being done on the matrilineal society in Meghalaya, the following research area was chosen.

Meghalaya is one of the seven states in the northeast region and one of the smallest in India. It is a strip of land surrounded by Bangladesh to the south and part of the west and Assam to the north and the east. The state has a predominantly agrarian economy with around $75 \%$ of its total population being engaged in agricultural activities.

The Khasi people form a major part of the population in the eastern part of Meghalaya and are the state's largest community. While almost $85 \%$ of the Khasi population have embraced Christianity, a minority still follow and practice their old age indigenous religion, known as the 'KaNiem Khasi' (Gurdon, 1904).

One of the most remarkable features of the Khasis that sets them apart from other tribes is that descendants trace their lineage through their mothers and not their fathers. In other words, the Khasi follow a unilineal principle of matrilineal descent (Nongkynrih, 2002). According to Khasi laws and traditions, the woman and her youngest daughter inherit property, and not the man. Women are free to choose their husbands and there are no societal pressures for marriage as opposed to a society in a patrilineal framework. Women also have the right to end the marriage without any objection from their husbands. While remarriage among women is more of a taboo in a patrilineal society, it is more of a usual activity among the Khasi women. Men and women are both free to remarry as many times as they wish to, in Khasi society.

After marriage, the eldest daughter moves out of her mother's house along with her husband to set up an independent residence. In such a situation, the 'Shnong' or the village administration provides the young couple with land for which there will be no ownership rights. Such a system of acquiring land is known as ' $R i$ Raid', while land acquired through lineage by the youngest daughter in the family is known as 'Ri Kynti'. However, land received by the Shnong is limited to the receiver's usage alone. 
This land received by the Shnong is then passed on from generation to generation following the true khasi matrilineal tradition. In the case of the demise of the couple, the land will be returned to the Shnong, under the circumstances of the absence of an heir. In case of marriage to the youngest daughter, it is the man who moves in with his wife's family.

With the youngest daughter being the sole heir to the inheritance, the elder daughters find it difficult to access bank loans as they have no valid legal documents to provide as collateral. In fact, even in the case of the youngest daughter, their husband or even brothers/uncles decide the use of the property like the agricultural land (Mukhim, 2008). While many families religiously follow the tradition of the youngest daughter inheriting ancestral property, with modernization, several families have also begun to desire to exercise the option of distributing land among children equally. However, this practice is still rare.

\section{Methodology}

In September 2016, a questionnaire survey was conducted for 28 days in Meghalaya. The research was conducted in two districts, East Khasi Hills and West Khasi Hills. Mawtawar (Village A) and Nongthliew (Village B) were the two research sites chosen because a majority of the residents were engaged in agricultural activities, similar to other typical rural communities. Mawtawar is a village situated in the district of East Khasi Hills, $15 \mathrm{kms}$ from the city center, with a population of around 980 households, while Nongthliew is a village situated in the district of West Khasi Hills, $38 \mathrm{kms}$ from the city center with a population of around 172 households. The distance between the two villages is around $58 \mathrm{kms}$.

Fifty female respondents were chosen at random from each village. The data of four respondents had to be eliminated, as they were unmarried and in addition 18 respondents had to be dropped as they were either widowed or separated, as it is difficult to check empowerment status unless they have a husband. The respondents had to be females engaged in agricultural activities. Each questionnaire was filled on a one-to-one basis. The respondents had to answer a questionnaire on the socio-economic characteristics of their household, such as information on family members, income, head of the family, and decision-making skills. The respondents were also questioned based on whether they had a savings account with a microfinance institution and if whether it was a joint account with their spouse or not. The questionnaire also covered their participation in a socio-economic group.

Jejeenhoy's (1997) study, explores the effects of a range of variables on women's autonomy. Measures of women's autonomy included their role in decision-making; mobility; incidence of domestic violence; access to, and control over, economic resources. For this research, the respondent's participation in a socio-economic group and her having a saving's account were chosen to check if she has decision making powers in the household and if she is empowered.

Social empowerment also includes the extent of freedom a woman has to participate in various social affairs, such as attending functions or meetings on community developmentrelated matters even outside their own village (Ghosh and Chowdhury, 2009). A socioeconomic group can empower a woman economically, socially, physically, and mentally. Such a group is a small homogenous affinity group of the rural poor who have volunteered to organize themselves into a group for eradication of poverty for their members (Dash, 2013). Women's participation in microcredit programs helps to increase women's empowerment. It is seen that there is a positive impact of women having a micro-savings account on both household decision-making power and self-perception of savings behavior (Ashraf and Yin, 
2009). To examine the empowerment status of women of the two areas, the following variables were regressed.

A probit estimation is applied to the following equation:

Socio-economic group $=\beta_{10}+\beta_{11}$ Household Characteristics $+\beta_{12}$ Empowerment Factors $+v$

Similarly, a probit estimation is applied to the following equation as well:

Savings Account $=\beta_{20}+\beta_{21}$ Household Characteristics $+\beta_{22}$ Empowerment Factors $+v_{2}$.

\section{Result and Discussion}

\subsection{Sample Characteristics}

From Table 1, the following deductions can be made; most of the Khasi women agreed with the fact that the girls in their community were more educated in comparison to the opposite gender. One of the major reasons being that the boys were required to help the family on the fields. In rural areas, children spending time in schools is considered to be time lost in economic sustainability of the family. According to statistics presented by NFHS (2009) of India, for 1081 girls around 1000 boys attended school between the age groups of 6-17. A government school at Nongthliew provides free education till class 5 for both genders. Along with this, the school also provides mid-day meals to the students. The staff including the teachers were women.

Table 1. Characteristics of Sample Household

\begin{tabular}{lcccc}
\hline \multicolumn{1}{c}{ Characteristics } & Unit & A & B & Total \\
\hline Age & Years & 40.76 & 41.36 & 42.91 \\
Spousal Age & Years & 45.30 & 43.19 & 44.29 \\
Education & Years & 6.74 & 8.19 & 7.44 \\
Spousal Education & Years & 6.79 & 5.36 & 6.10 \\
Second Marriage & Years & 11.62 & 5.71 & 9.2 \\
Spousal second marriage & Years & 16.27 & 14.28 & 15.38 \\
Age at marriage of woman & Years & 19.88 & 21.21 & 20.59 \\
Percentage of Girls & $\%$ & 47.74 & 46.65 & 47.20 \\
Land (Ri kynti) & $\%$ & 81.39 & 100 & 90.69 \\
Socio-economic group & $\%$ & 13.3 & 43.1 & 28.2 \\
Savings Account & $\%$ & 65 & 100 & 82.5 \\
\hline Sample Size & & 43 & 35 & 78
\end{tabular}

Source: Own Survey, 2016

It is seen that adults who are educated are more likely to get their children educated (NFHS,2009). It was observed that $13.3 \%$ of the women in Village A and $43.1 \%$ of the women in Village B, were a part of a socio-economic group. $65 \%$ of the women in Village A had a savings account, while it was observed that every respondent in Village B had a savings account. It was also seen that all the respondents of Village B inherited land through lineage (Ri kynti), while $65 \%$ of the respondents from Village A inherited land through lineage. Most of the women 
who participated in socio economic activities were from West Khasi Hills as well as majority of the women who owned land through Ri kynti were also found to be from the same district.

\subsection{Determinants of Empowerment Status}

The household characteristics as well as the empowerment and economic factors used in the probit models are summarized in Table 2.

Table 2. Descriptive Status of the Explanatory Variables

\begin{tabular}{|c|c|c|c|c|}
\hline Variables & Unit & Description & Mean & St.Dev \\
\hline \multicolumn{5}{|l|}{ Dependent variables } \\
\hline Socio-economic group & Dummy & $\begin{array}{l}\text { Take } 1 \text {, if she is a part of Socio-economic } \\
\text { activity }\end{array}$ & 0.28 & 0.45 \\
\hline Savings Account & Dummy & $\begin{array}{l}\text { Take } 1 \text {, if the female respondent has a } \\
\text { Savings Account }\end{array}$ & 0.84 & 0.36 \\
\hline \multicolumn{5}{|l|}{$\begin{array}{l}\text { Household } \\
\text { Characteristics }\end{array}$} \\
\hline Age & Years & Age of the female respondent & 41.05 & 11.52 \\
\hline Spousal Age & Years & Age of the male respondent & 44.29 & 12.59 \\
\hline Educational Qualification & Years & Years of schooling of female respondent & 7.44 & 4.4 \\
\hline $\begin{array}{l}\text { Spousal Educational } \\
\text { Qualification }\end{array}$ & Years & Years of schooling of husband & 6.10 & 2.85 \\
\hline Second Marriage & Dummy & $\begin{array}{l}\text { Take } 1 \text {, if female respondent married } \\
\text { again }\end{array}$ & 0.08 & 0.27 \\
\hline Spousal Second Marriage & Dummy & Take 1 , if male respondent married again & 0.17 & 0.38 \\
\hline $\begin{array}{l}\text { Age at Marriage of } \\
\text { Woman }\end{array}$ & Years & Age at marriage of female respondent & 20.23 & 3.15 \\
\hline Percentage of Girls & $\%$ & Percentage of Girls in the Household & 47.37 & 17.22 \\
\hline \multicolumn{5}{|l|}{ Empowerment Factors } \\
\hline Land Ri Kynti & Dummy & $\begin{array}{l}\text { Take } 1 \text {, if the female respondent owns } \\
\text { land }\end{array}$ & 0.56 & 0.49 \\
\hline
\end{tabular}

Note 1) Sample Size:78

Source: Own Survey, 2016

Table 3 shows the results of our estimation. It shows the relationships of female respondent's participation in socio-economic activities and having a savings account with the other possible functions.

The positive effect of Ri kynti on socio-economic group means that women who inherit land through lineage and own it are more likely to join a socio-economic group. Participating in social economic activities gives much power to a woman in a society. 
It was also seen that there was a positive effect of Ri kynti on savings account. Land is the only or major asset of the rural women that they can use as collateral security in acquiring bank loans (Toro, 2016). This explains the positive relation of land received by the woman through inheritance (Ri kynti) and her having a savings account

Other than this, two other significant factors shown in the result were that of the negative impact of husband's educational qualification on both socio-economic group and savings account. This means that higher the educational qualification of the husband, the less likely for the woman to join a socio-economic group and have a savings account. From this we can deduce, that women tend to have less freedom and choices if the educational level of their husband is higher than theirs.

Table 3. Probit Analysis of Socio-economic group and Savings Account

\begin{tabular}{lcccc}
\hline \multicolumn{1}{c}{ Variables } & \multicolumn{2}{c}{ Socio-economic Group } & \multicolumn{2}{c}{ Savings Account } \\
\cline { 2 - 5 } & $\beta$ & $\mathrm{P}>|\mathrm{z}|$ & $\beta$ & $\mathrm{P}>|\mathrm{z}|$ \\
\hline Age & 0.03 & 0.54 & -0.09 & $0.09^{*}$ \\
Spousal Age & -0.03 & 0.51 & 0.04 & 0.46 \\
Educational Qualification & 0.01 & 0.66 & 0.00 & 0.90 \\
Spousal Educational Qualification & -0.10 & $0.09 *$ & -0.12 & $0.09^{*}$ \\
Second Marriage & -0.79 & 0.30 & -0.83 & 0.14 \\
Spousal Second Marriage & 0.26 & 0.65 & -0.53 & 0.41 \\
Age at marriage of woman & -0.04 & 0.38 & 0.00 & 0.89 \\
Percentage of Girls & 0.18 & 0.11 & 0.19 & 0.17 \\
Ri kynti & 0.90 & $0.02 * *$ & 0.79 & $0.01 * *$ \\
\hline Pseudo R2 & 0.15 & & 0.24 & \\
Correctly Classified & $76 \%$ & $85.3 \%$ & \\
\hline
\end{tabular}

Note: 1$) * * *, * * *$ indicates significances $1 \%, 5 \%$ and $10 \%$ levels respectively

2) Sample survey $=78$, Own Survey, 2016

Source: Author's Estimation 
Along with this, the negative impact of a women's age on saving's account, means that older women tend to not have a saving's account, giving the impression that they may not be acquainted well with owning one or that they find the procedure of opening an account with a microfinance institution complicated.

Other than these factors, from the results it can also be seen that a spousal's age, second marriage of the wife, second marriage of the husband, age at marriage of the wife, educational qualification of the wife, educational qualification of the husband and the percentage of girls in the family had no significance.

\section{Conclusion}

In summary, to check whether land ownership of women empowers them and if whether it gives them decision making power in the household in a matrilineal society, we can conclude from our findings that the women who owned land through Ri kynti were empowered. However, in a Khasi society women's customary rights over land continues to mainly be limited to that of a custodian, which still gives them a certain amount of bargaining power. From the survey conducted, women may be more empowered when they receive land through their lineage ( $R i \mathrm{kynti}$ ) in contrast to the ones who received land through the Shnong (Ri raid). However, the fact that they still consider their husband to be the head of the family, makes us consider that there may be a psychological component to it.

\section{Acknowledgements}

This work was supported by the Japan Society for the Promotion of Science (JSPS) KAKENHI (grant number 17H05036).

\section{References}

Agarwal, B. (2000) Gender, Land and Livelihood in South Asia. CPD Dialogue Repot No. 30, pp.6.

Agarwal, B. (1994) A field of one's own: Gender and land rights in South Asia. Cambridge: Cambridge University Press.

Agarwal, B. (1997). Bargaining and gender relations: Within and beyond the household. Feminist Economics, 2(1), 1-50.

Andrea, F. (2015) The Economic Case for Funding Planned Parenthood. https://www.theatlantic.com/business/archive/2015/09/planned-parenthoodeconomic-benefits/405922/, [Accessed on November, 2016].

Ashraf,N., Karlan, D., Yin,W. (2010) Female Empowerment: Impact of a Commitment savings Product in the Philippines. World Development Vol.38, No.3, pp 338.

Toro, B. (2016), Rural Women and the Land Question in Zimbabwe: The Case of the Mutasa District. International Journal of African Development, Vol.4, pp 77-87.

Braunstein, E., Folbre, N. (2001) To honor and obey: efficiency, inequality, and patriarchal property right. Feminist Economics, 7 (1) ,25-44.

Chacko, E. (2003), "Marriage, development, and the status of women in Kerala, India". Gender and Development, Vol.11, 52-59.

Dash, MK. (2013) Role of Self Help Groups in Empowerment of women: A Study in Bargah. Odisha Review, pp.71- 75. 
Duflo, E. (2012) Women Empowerment and Economic Development. Journal of Economic Literature, Vol.50, No.4, pp 1051-1079

Giovarelli, R., Wamalwa, B. (2011) Land tenure, property rights, and gender: Challenges and approaches for strengthening women's land tenure and property rights (USAID Issue Brief- Property rights and resource governance briefing paper \#7). New York: United States Agency International Development (USAID). Retrieved 6 June 2014, pp.1-9.

Ghosh, BN., Chowdhury, JR. (2009) Empowerment of Khasi Women in Meghalaya- A Case Study. Journal of Empirical Research in Social Science Volume 4, pp.68-80.

Gurdon, P. R. T. (1904) Note on the Khasis, Syntengs, \& allied Tribes. Journal of the Asiatic Society of Bengal. 73 (4), pp.63.

Haddad, L., Hoddinott, J., \& Alderman, H. (1997). Intrahousehold resource allocation in developing countries: Models, methods, and policies. Washington, DC: International Food Policy Research Institute.

Htun, M., Weldon, L. 2011. "Sex Equality in Family Law: Historical Legacies, Feminist Activism, and Religious Power in 70 Countries." Background Paper for the World Development Report 2012

Jeffrey, R. (2005), "Legacies of Matriliny: The Place of Women and the "Kerala Model'", Pacific Affairs, Vol.77, 647-664.

Jejeebhoy, S. (1997), 'Operationalizing women's Empowerment: The Case of Rural India', paper presented at the Seminar on Female Empowerment and Demographic Processes, Lund (20-24 April).

Kumar, U., Ghosh, BN. (2007) Status of women in the Rural Khasi Society of Meghalaya. MPRA Paper No. 6290.

Kurian, G. (2004), "Patriarchy in Transition: Women and the Changing Family in the Middle East", Turbulent Times and Family Life in the Contemporary Middle East, Vol.35, No.2, 137-162.

Kulwiki, AD. (2002), "The Practice of Honor Crimes: A Glimpse of Domestic Violence in the Arab World", Issues in Mental Health Nursing, Vol 23, Issue 1, 77-87.

Malhotra, A., \& Schuler, S. R. (2005). Women's Empowerment as a Variable in International Development. In Deepa Narayan (Ed.), Measuring empowerment: Cross-disciplinary perspectives (pp. 71-88). Washington, DC: The World Bank.

Mawrie, B. (2015). "Let's save our tradition!". The Shillong Times, http://www.theshillongtimes.com/2015/01/23/letssave-ourtradition [Accessed on 22 October, 2017].

Mitra, A., \& Singh, P. (2007)," Human Capital Attainment and Gender Empowerment: The Kerala Paradox". Social Science Quarterly, 1227-1242.

Mukhim, P. (2008) Land Ownership among the Khasis of Meghalaya: A Gender Perspective. North Eastern Social Research Centre and IWGIA. pp- 38-52.

Murdock, G. P., \& White, D. R. (1969). Standard cross-cultural sample. Ethnology, 8, $329-369$

National Family Health Survey India (2009) Gender Equality and Women Empowerment in India, pp. 81,120-123.

Nongkynrih, AK. (2002) Khasi Society of Meghalaya- A Sociological Understanding, pp.11-33. 
Pakyntein, V. 1999. "Gender preference in Khasi society". In Wonder That Is Culture, edited by T. B. Subba, pp. 171-182. New Delhi: Mittal Publications.

Pati.R.N. (2003) Socio-cultural dimensions of reproductive child health. APH Publishing. ISBN 978-81-7648-510-4, pp. 51.

Roy, S. (2017) Political Economy of Land Governance and Women's Rights-The Case of Meghalaya. The World Bank.

Rosenthal, CJ., \& Marshall, VW. (1986) The Head of the Family: Social Meaning and Structural Variability. The Canadian Journal of Sociology Vol.11, No.2, pp.598.

UNDP (2015). $\quad$ http://www.in.undp.org/content/india/en/home/post-2015/sdgoverview/goal-5.html [Accessed on February, 2018]

Unni, J. (1999) Property rights for women: Case for joint titles to agricultural land and urban housing. Economic and Political Weekly, 34. 